\title{
PEMBUATAN BIOGAS DARI BAHAN SAMPAH SAYURAN (KUBIS, KANGKUNG dan BAYAM)
}

\author{
Oleh : Joko Sutrisno *)
}

\begin{abstract}
ABSTRAK
Sampah sayur di pasar-pasar tradisional sangat berlimpah jumlahnya, terdiri dari beberapa bahan buangan sisa proses penyortiran untuk dijual seperti sayur kangkung,. Kubis, bayam, sawi, daun ubi jalar,daun ubi kayu, kacang panjang dan brokoli. Sesungguhnya semua sisa sayur yang akhirnya menjadi sampah ini dapat dimanfaatkan untuk dijadikan bahan guna diproses agar menghasilkan gas bio yang merupakan energi panas alternative dengan bahan baku dapat diperbarui. Melalui alat digester biogas yang disiapkan pada ukuran kecil untuk skala rumah tangga, kebutuhan energi panas untuk keperluan memasak dapat dipenuhi dari proses ini. Penelitian ini merupakan percobaan pembuatan gas bio dengan bahan sampah sayur basah dari pasar tradisional berupa 3 variasi bahan yaitu kangkung, bayam dan kubis, yang dihaluskan terlebih dahulu dengan mesin perajang sampah. Untuk mempercepat proses digunakan starter berupa bakteri Effektive Microorganisme (EM4) yang banyak beredar di pasaran. Hasil percobaan menunjukan bahwa ketiga bahan sayuran tersebut dapat dijadikan bahan pembuatan gas bio, dengan tekanan produk maksimal yang tidak signifikan perbedaannya.
\end{abstract}

Kata Kunci: Biogas, Tekanan, Sampah Sayuran, Kubis, Kangkung dan Bayam.

\section{PENDAHULUAN \\ Latar Belakang Masalah}

Energi gas bio dihasilkan dari proses fermentasi bahan-bahan organik dengan bantuan bakteri anaerob pada lingkungan tanpa oksigen bebas. Energi gas bio didominasi gas metan $(55 \%$ - $75 \%)$, karbondioksida $(25 \%-45 \%)$ dan beberapa gas lain dalam jumlah lebih kecil. Gas metan termasuk gas rumah kaca (greenhouse gas), bersama dengan gas karbon dioksida (CO2) memberikan efek rumah kaca yang menyebabkan terjadinya fenomena pemanasan global. Pengurangan gas metan secara lokal ini dapat berperan positif dalam upaya penyelesaian permasalahan global. Pada dasarnya pembuatan gas bio sangat sederhana, hanya dengan mencampurkan substrat EM4 pada sampah organik yang dimasukkan ke dalam digester yang anaerob. Dalam waktu tertentu gas bio akan terbentuk yang selanjutnya dapat dimanfaatkan sebagai sumber energi, misalnya untuk kompor gas atau listrik. Dengan adanya energi alternatif yang nyata sebagai pengganti Bahan Bakar Minyak (BBM) yang penggunaannya cukup tinggi.

Pembuatan energi alternatif biogas sangatlah relatif mudah, dimana dapat kita pergunakan sampah organik sebagai bahan dasar pembuatannya, dengan mefungsikan drum bekas sebagai unit reaktor biogas, agar proses pendegrasian sampah organik tersebut berjalan cepat, maka sampah organik dicincang terlebih dahulu sebelum dimasukkan kedalam reaktor.

Sampah organik berpotensi untuk dapat dimanfaatkan sebagai bahan pembuatan gas bio, namun belum banyak dimanfaatkan. Bahkan selama ini telah menimbulkan masalah pencemaran yang berdampak pada kesehatan lingkungan. Umumnya sampah organik yang dihasilkan dari aktivitas pasar setiap harinya yang dapat meningkatkan volume sampah dan pada akhirnya menimbulkan bibit penyakit dari pembusukkan sampah organik tersebut.

\section{Perumusan Masalah}

1. Apakah jenis bahan sampah sayuran akan menghasilkan tekanan produk biogas yang berbeda - beda

2. Berapakah lama produksi gas yang dihasilkan untuk setiap jenis bahan sampah sayur?

\section{Variabel Penelitian}

a. Variabel Bebas (independent variable) Variabel bebas dalam penelitian ini adalah jenis sayur sebagai bahan pembuat biogas yaitu:

- Variasi 1, sampah sayuran Kubis

- Variasi 2, sampah sayuran

Kangkung

- Variasi 3, sampah sayuran Bayam

*)Penulis adalah dosen Teknik Lingkungan

Universitas PGRI Adi Buana Surabaya

108 Jurnal Teknik WAKTU Volume 08 Nomor 01 Januari 2010 - ISSN : 1412 - 1867 
b. Variabel Terikat (dependent variable)

1. Tekanan gas yang dihasilkan

2. Waktu yang dibutuhkan sampai dengan menghasilkan gas bio.

c Variabel yang dikontrol

1. Volume bahan

2. Perbandingan campuran bahan dengan air $(1: 1)$

3. Jenis dan jumlah stater yaitu menggunakan EM4 $500 \mathrm{ml}$ / sampel.

4. Perlakuan pada bahan, yaitu dihancurkan dengan mesin pencacah sampah.

\section{Tujuan Penelitian}

1. Untuk mengetahui seberapa besar tekanan gas bio yang dihasilkan oleh setiap bahan sampah sayuran .

2. Untuk mengetahui lama produksi gas yang dihasilkan dari input sampai dengan bertekanan maksimal.

\section{E. Manfaat Penelitian}

1. untuk mengetahui apakah dari bahan sampah sayuran khususnya bayam, kangkung dan kubis, dapat dimanfaatkan sebagai bahan pembuatan biogas.

2. Sebagai bahan informasi kepada kemasyarakat akan pemanfaatan sampah organik disekitar kita untuk dapat digunakan sebagai sumber energi alternatif.

\section{TELAAH PUSTAKA}

\section{A. Biogas}

Secara garis besar bahan baku yang diperlukan adalah biomassa (residu mahluk hidup), mikroorganisme, dan air. Produk utama dari biogas ini adalah gas metana dan pupuk organik. Gas metana telah dikenal luas sebagai bahan ramah lingkungan, karena dapat terbakar sempurna sehingga tidak menghasilkan asap yang berpengaruh buruk terhadap kualitas udara. Karena sifatnya tersebut, gas metana merupakan gas yang bernilai ekonomis tinggi dan dapat dimanfaatkan untuk berbagai keperluan mulai dari memasak, hingga penggerak turbin pembangkit listrik tenaga uap.

Biogas adalah gas yang mudah terbakar (flammable gas) yang diperoleh dari penguraian senyawa-senyawa organik dalam biomassa sebagai akibat aktivitas mikroorganisme (fermentasi) pada kondisi tanpa udara (anaerobic). Kandungan utama biogas adalah gas metana $\left(\mathrm{CH}_{4}\right)$ dan karbon dioksida $\left(\mathrm{CO}_{2}\right)$. Sebagian kecil adalah gas hidrogen sulfida $\left(\mathrm{H}_{2} \mathrm{~S}\right)$, nitrogen $\left(\mathrm{N}_{2}\right)$, hidrogen $\left(\mathrm{H}_{2}\right)$ dan oksigen $\left(\mathrm{O}_{2}\right)$. Kehadiran gas metana yang besar ini membuat biogas mudah terbakar dan dapat dipakai sebagai sumber energi untuk memasak, penerangan, bahkan pada skala besar dapat menghasilkan energi listrik.

Biogas ini juga menghasilkan produk samping berupa lumpur organik yang dapat diolah menjadi pupuk kompos. Kualitas pupuk kompos yang dihasilkan tergantung pada bahan baku yang digunakan. Pengolahan lanjutan limbah biogas menjadi kompos bukanlah hal yang sulit untuk dilakukan. Pengolahan dilakukan dengan cara memisahkan cairan (bisa digunakan sebagai pupuk cair) dengan padatan melalui proses penyaringan. Kemudian padatannya dikeringkan dan ditambahkan bahan-bahan lain untuk mencapai komposisi senyawa kompos yang diinginkan seperti kandungan nitrogen $(\mathrm{N})$, phosfor $(\mathrm{P})$, kalium $(\mathrm{K})$, magnesium $(\mathrm{Mg})$, kalsium $(\mathrm{Ca})$, dan mineralmineral lainnya. Bahkan unsur - unsur tertentu seperti protein, selulosa, lignin dan lain - lain tidak bisa digantikan oleh pupuk kimia.

Tabel 1. Komposisi Dalam Biogas.

\begin{tabular}{|c|r|}
\hline Komponen & Prosentase \\
\hline Metana $\left(\mathrm{CH}_{4}\right)$ & $55-75$ \\
Karbon dioksida $\left(\mathrm{CO}_{2}\right)$ & $25-45$ \\
Nitrogen $\left(\mathrm{N}_{2}\right)$ & $0-0.3$ \\
Hidrogen $\left(\mathrm{H}_{2}\right)$ & $1-5$ \\
Hidrogen sulfida $\left(\mathrm{H}_{2} \mathrm{~S}\right)$ & $0-3$ \\
Oksigen $\left(\mathrm{O}_{2}\right)$ & $0.1-0.5$ \\
Sumber :www.unsoed.ac.id
\end{tabular}

Sumber :www unsoed ac.id

Mekanisme Pembentukan Biogas sampah organik sayur-sayuran dan buahbuahan seperti layaknya kotoran ternak adalah substrat terbaik untuk menghasilkan biogas (Hammad et al, 1999). Proses pembentukan biogas melalui pencernaan anaerobik merupakan proses bertahap, dengan tiga tahap utama, yakni hidrolisis, asidogenesis, dan metanogenesis. Tahap pertama adalah hidrolisis, dimana pada tahap ini bahan-bahan organik seperti karbohidrat, lipid, dan protein didegradasi oleh mikroorganisme hidrolitik menjadi senyawa terlarut seperti asam karboksilat, 
asam keto, asam hidroksi, keton, alkohol, gula sederhana, asam-asam amino, $\mathrm{H}_{2}$ dan $\mathrm{CO}_{2}$. Pada tahap selanjutnya yaitu tahap asidogenesis senyawa terlarut tersebut diubah menjadi asam-asam lemak rantai pendek, yang umumnya asam asetat dan asam format oleh mikroorganisme asidogenik. Tahap terakhir adalah metanogenesis, dimana pada tahap ini asam-asam lemak rantai pendek diubah menjadi $\mathrm{H}_{2}, \mathrm{CO}_{2}$, dan asetat. Asetat akan mengalami dekarboksilasi dan reduksi $\mathrm{CO}_{2}$, kemudian bersama-sama dengan $\mathrm{H}_{2}$ dan $\mathrm{CO}_{2}$ menghasilkan produk akhir, yaitu metana $\left(\mathrm{CH}_{4}\right)$ dan karbondioksida $\left(\mathrm{CO}_{2}\right)$. Pada dasarnya efisiensi produksi biogas sangat dipengaruhi oleh berbagai faktor meliputi : suhu, derajat keasaman $(\mathrm{pH})$, konsentrasi asam - asam lemak volatil, nutrisi (terutama nisbah karbon dan nitrogen), zat racun, waktu retensi hidrolik, kecepatan bahan organik, dan konsentrasi amonia. Beberapa kondisi optimum proses produksi biogas yaitu:

Tabel 2. Kondisi Optimum Produksi Biogas

\begin{tabular}{|l|l|}
\hline \multicolumn{1}{|c|}{ Parameter } & \multicolumn{1}{|c|}{ Kondisi Optimum } \\
\hline Suhu & $35^{\circ} \mathrm{C}$ \\
Derajat Keasaman & $7-7,2$ \\
Nutrien Utama & Karbon dan Nitrogen \\
Nisbah Karbon dan Nitrogen & $20 / 1 \mathrm{sampai} 30 / 1$ \\
Sulfida & $<200 \mathrm{mg} / \mathrm{L}$ \\
Logam-logam Berat Terlarut & $<1 \mathrm{mg} / \mathrm{L}$ \\
Sodium & $<5000 \mathrm{mg} / \mathrm{L}$ \\
Kalsium & $<2000 \mathrm{mg} / \mathrm{L}$ \\
Magnesium & $<1200 \mathrm{mg} / \mathrm{L}$ \\
Amonia & $<1700 \mathrm{mg} / \mathrm{L}$ \\
\hline Sumber :www.unsoed.ac.id Pengolahan Limbah Organik \\
\multicolumn{1}{|c|}{ Menjadi Biogas (2004) }
\end{tabular}

Parameter - parameter ini harus dikontrol dengan cermat supaya proses pencernaan anaerobik dapat berlangsung secara optimal. Sebagai contoh pada derajat keasaman $(\mathrm{pH}), \mathrm{pH}$ harus dijaga pada kondisi optimum yaitu antara $7-7,2$. Hal ini disebabkan apabila $\mathrm{pH}$ turun akan menyebabkan pengubahan substrat menjadi biogas terhambat sehingga mengakibatkan penurunan kuantitas biogas. Nilai $\mathrm{pH}$ yang terlalu tinggipun harus dihindari, karena akan menyebabkan produk akhir yang dihasilkan adalah $\mathrm{CO}_{2}$ sebagai produk utama.
Begitupun dengan nutrien, apabila rasio $\mathrm{C} / \mathrm{N}$ tidak dikontrol dengan cermat, maka terdapat kemungkinan adanya nitrogen berlebih (terutama dalam bentuk amonia) yang dapat menghambat pertumbuhan dan aktivitas bakteri.

Berdasarkan keterangan tentang potensi biogas dari sampah sayuran, maka dapat ditunjukan hubungan antara aktivitas manusia kaitannya dengan penggunaan biogas dengan jumlah volume biogas yang digunakan seperti yang terlihat pada tabel dibawah ini.

Tabel 3 Hubungan Antara Aktivitas Manusia dengan Volume Biogas yang digunakan.

\begin{tabular}{|l|c|}
\hline \multicolumn{1}{|c|}{ Aktifitas } & Volume Gas \\
\hline Memasak untuk keluarga yang jumlahnya $5-6$ orang & $2 \mathrm{~m}^{3} /$ hari \\
\hline Memasak air dengan kapasitas tangki 100 liter & $3 \mathrm{~m}^{3} / \mathrm{hari}$ \\
\hline Menyalakan 1 lampu & $0,1-0,15 \mathrm{~m}^{3} / \mathrm{jam}$ \\
\hline Mengoperasikan mesin dengan kekuatan 2 tenaga kuda & $0,9 \mathrm{~m}^{3} / \mathrm{jam}$ \\
\hline
\end{tabular}

Sumber : Direktorat Jendral Pertanian; 2006

108 Jurnal Teknik WAKTU Volume 08 Nomor 01 Januari 2010 - ISSN : 1412 - 1867 


\section{B. Proses Anaerobik dalam Biogas}

Proses pengolahan limbah secara anaerobik merupakan metode yang efektif untuk mengolah berbagai macam limbah organik. Pengolahan ini dimediasi oleh mikroorganisme anaerobik dan mikroorganisme fakultatif yang tidak membutuhkan oksigen yang kemudian mengubah zat - zat organik manjadi produk akhir seperti karbon dioksida $\left(\mathrm{CO}_{2}\right)$ dam metana $\left(\mathrm{CH}_{4}\right)$. Keuntungan utama pengolahan limbah secara anaerobik dibanding dengan pengolahan secara aerobik adalah sebagai berikut : a. Menghasilkan biomasa yang relatif lebih sedikit.

b. Mempunyai nilai ekonomis karena menghasilkan gas metan yang bisa digunakan untuk bahan bakar

c. Mampu mengolah bahan organik yang tinggi karena tidak membutuhkan oksigen yang lebih banyak.

Biogas terjadi akibat reaksi anaerobik bahan organik. Menurut Larry $D$. Benefield dan Clifford W. Randal reaksi fermentasi pembentukan biogas adalah sebagai berikut :

Asam Asetat :

$$
\mathrm{CH}_{3} \mathrm{COOH} \rightarrow \mathrm{CH}_{4}+\mathrm{CO}_{2}
$$

Asam Propionat :

$$
\text { 1. } \begin{aligned}
\mathrm{CH}_{3} \mathrm{CH}_{2} \mathrm{COOH}+0,5 \mathrm{H}_{2} \mathrm{O} & \rightarrow \mathrm{CH}_{3} \mathrm{COOH}+0,25 \mathrm{CO}_{2}+0,75 \mathrm{CH}_{4} \\
\text { 2. } \mathrm{CH}_{3} \mathrm{COOH} & \rightarrow \mathrm{CH}_{4}+\mathrm{CH}_{2}
\end{aligned}
$$

Reaksi keseluruhannya :

$$
\mathrm{CH}_{3} \mathrm{CH}_{2} \mathrm{COOH}+0,5 \mathrm{H}_{2} \mathrm{O} \rightarrow 1,25 \mathrm{CO}_{2}+1,75 \mathrm{CH}_{4}
$$

Dari kedua reaksi diatas menunjukan bahwa hanya satu golongan bakteri metan yang dibutuhkan untuk proses fermentasi bahan organik. Asam asetat dan asam propionat yang difermentasi terdiri dua golongan yang berbeda untuk bakteri metan.

Bakteri yang bertanggung jawab untuk asam asetat secara relatif mengalami perubahan di $\mathrm{pH}$ dan temperatur serta mempunyai perkembangan yang jauh lebih tinggi bila dibandingkan dengan bakteri pada gas metana. Sebagai hasilnya gas metana biasanya diasumsikan untuk menjadi bahan pengendalian dalam proses anaerobik.

Berikut adalah gambar proses pembentukan gas metana $\left(\mathrm{CH}_{4}\right)$ secara anaerobik dari bahan organik seperti yang terlihat pada gambar 1 berikut ini.

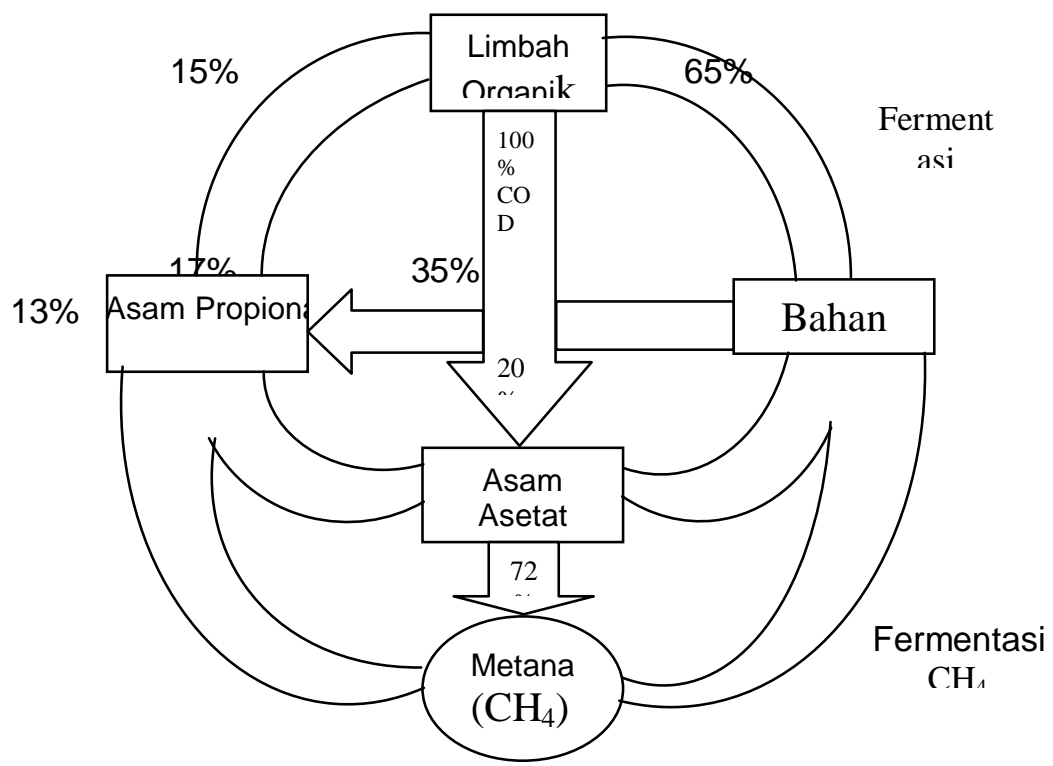

Gambar 1. Proses Fermentasi Bahan Organik 


\section{Karakteristik Kandungan Sampah Sayuran}

Menurut Djuarnani, dkk (1995), sampah organik yang dihasilkan dari aktivitas tumbuhan hasil pemeliharaan dan budi daya, dapur rumah tangga, pasar, mengandung lebih banyak bahan organik yang mudah membusuk, lembab, dan mengandung sedikit cairan. Karena banyak mengandung bahan organik, limbah ini dapat terdekomposisi secara cepat, terutama ketika cuaca hangat. Limbah ini dapat mengeluarkan bau busuk. Komponen dan komposisi bahan sampah organik dapat dilihat pada tabel dibawah ini.

Tabel 4. Komponen dan komposisi bahan sampah organik

\begin{tabular}{|l|c|}
\hline \multicolumn{1}{|c|}{ Komponen } & Kandungan \\
\hline Air (\%) & $30,0-60,0$ \\
Serat kasar (\%) & $4,1-6,0$ \\
Lemak (\%) & $3,0-9,0$ \\
Amonium (mg/g sampah) & $0,5-1,14$ \\
N organik (mg/g sampah) & $4,8-14,0$ \\
Total nitrogen (mg/g sampah) & $4,0-17,0$ \\
Protein (mg/g sampah) & $3,1-9,3$ \\
Keasaman (pH) & $5,0-8,0$ \\
\hline
\end{tabular}

Sumber : Hadiwiyoto (1983)

\section{J. Komposisi Kandungan Jenis Sampah Sayuran}

1. Kubis

Kubis adalah tanaman sayuran yang memiliki kasiat yang begitu besar. Sayur ini juga mengandung vit. $\mathrm{C}$, maka ia juga berkhasiat melawan penyakit kanker, dan melindungi perut serta usus besar dari menjalarnya sel-sel penyakit kanker, terutama organ pencernaan tubuh. Selain itu, kubis berkhasiat untuk membasmi segala macam bakteri dan mikroba yang membahayakan tubuh karena kubis mengandung sulfur yang tinggi. Sayur kubis juga berkhasiat mengobati bronchitis dan meningkatkan aktivitas kedua ginjal. Sayur kubis juga termasuk salah satu komponen obat yang dapat menyembuhkan penyakit adiksi dan menetralisir darah dalam tubuh. Dari berbagai macam kasiat dari tanaman Kubis tersebut memiliki komposisi gizi Dalam setiap $100 \mathrm{fgr}$ sayur kubis terkandung $1,4 \mathrm{gr}$ zat protein $+0,02$ gr lemak $+5,3$ gr karbohidrat +80 gr vit. $A+0,06$ gr vit. $B 1+$ vit. $B 2$, nisin, dan mineral2 seperti kalsium, potasium, fosfor dan zat besi.

2. Kangkung

Tumbuhan asli India ini umumnya mempunyai ukuran tinggi 1-3 m, bercabang banyak. Batang berkayu, bulat, berbuku-buku, berambut, hijau kecokelatan. Daun tunggal, berhadapan, helaian elips sampai lanset, ujung dan pangkal runcing, tepi rata, tulang daun menyirip, kedua permukaan berambut, panjang $4-8 \mathrm{~cm}$, lebar $1-3 \mathrm{~cm}$, warnanya hijau atau hijau kekuningan. Bunga tunggal atau berpasangan, di ketiak daun dan ujung tangkai, mahkota berambut kelenjar, bibir atas mahkota berbagi empat, bulat telur, warnanya ungu. Buah elips, panjang $1,5 \mathrm{~cm}$, berbibir tiga sampai empat, kecokelatan. Biji kecil, pipih, warna cokelat. Nilai nutrisi setiap 100 gram kangkung yang direbus tanpa garam mengandung air $91,2 \mathrm{gr}$, energi $28 \mathrm{kkal}$, protein 1,9 gr, lemak 0,4 gr, karbohidrat 5,63 gr, serat 2 gr, dan ampas $0,87 \mathrm{gr}$. Kangkung juga kaya vitamin $A, B, C$, mineral, asam amino, kalsium, fosfor, karoten, dan zat besi.

3. Bayam

Bayam (Spinacea oleracea) adalah tumbuhan yang berasal dari Amerika dan Selandia Baru. Karena mudah tumbuh di mana saja, kini bayam sudah sangat dikenal di Indonesia. Bila di negara kita bayam telah dikonsumsi secara luas, di Eropa dan Australia, pada awalnya tanaman ini lebih dikenal sebagai tanaman hias yang banyak dijumpai di sudut-sudut kota. Barulah sekitar tahun 1960-an, penduduk Australia mulai melirik bayam sebagai salah satu bahan makanan yang ternyata memiliki kandungan protein yang sangat tinggi. Sayuran ini memang sangat sederhana. Tetapi bayam memiliki kandungan gizi yang sangat 
lengkap dan penting untuk tubuh kita selama ini, Kandungan mineral dalam bayam cukup tinggi, terutama $\mathrm{Fe}$ (zat besi) yang dapat digunakan mencegah kelelahan akibat anemia. Karena kandungan $\mathrm{Fe}$ dalam bayam cukup tinggi, ditambah kandungan Vitamin B terutama asam folat. Baik mineral $\mathrm{Fe}$ atau asam folat berhubungan dengan produksi darah.Tidak hanya itu, kandungan asam oxalat dan asam folat juga membuat sayur bayam dapat membantu mengatasi berbagai macam penyakit. Misalnya mengobati eksem, asma, untuk perawatan kulit muka, kulit kepala dan rambut, menurunkan kadar kolesterol, serta mencegah sakit pada gusi. Tetapi, manfaat yang besar adalah untuk mengobati rasa lesu, letih, dan kurang bergairah sebagai tanda kurang darah atau anemia. Bayam juga sangat baik sebagai sumber protein, terutama asam amino yang baik untuk pembentukan otak. Jadi, jika dilihat dari komposisi proteinnya, bayam sangat baik untuk dikonsumsi anak-anak. Dari segi lemak, kolesterol dalam bayam nol, artinya bayam aman untuk dikonsumsi sebanyak apapun tanpa ada pengaruh kolesterol. Lemak yang terdapat dalam bayam juga termasuk lemak yang jenisnya baik, yaitu lemak tidak jenuh. Vitamin dalam bayam sangat penting, misalnya vitamin A yang bagus untuk mata serta mempertahankan daya tahan tubuh sehingga orang tidak mudah terserang penyakit. Vitamin $\mathrm{C}$ dan $\mathrm{E}$ untuk antioksidan sehingga bagi yang rajin mengonsumsi bayam, bisa memiliki kulit yang halus. Selain itu, antioksidan juga mampu mencegah radikal bebas. Kemudian fosfor dapat dimanfaatkan untuk pembentukan tulang dan gigi.

Kandungan negatif dalam bayam juga terdapat kandungan senyawa kimia yang bersifat negatif, yaitu asam oxalate. Kandungan ini dapat menurunkan penyerapan beberapa kandungan zat gizi yang ada pada bayam seperti $\mathrm{Fe}$. Zat ini hanya dapat diserap 53 persen dan kalsium sebanyak 5 persen. Caranya, sebaiknya bayam dikonsumsi setelah lebih dari lima jam atau dihangatkan karena akan menyebabkan asam oxalat larut. "Jangan dikonsumsi setelah lebih dari lima jam atau dihangatkan karena akan menyebabkan asam oxalat lebih banyak keluar bayam juga mengandung zat nitrat (NO3). Kalau teroksidasi udara, akan menjadi NO2 (nitrit). Nitrit adalah senyawa yang tidak berwarna, tidak berbau, dan bersifat racun bagi tubuh manusia (Marzuki Iskandar, 2004)

\section{METODE}

\section{A. Replikasi Percobaan}

Untuk memperoleh reliabilitas dan validitas data yang diambil dari sampel ini, maka diadakan percobaan sebanyak 3 kali untuk tiap variasi variabel bebas.

\section{B. Metode Pengumpulan Data}

Untuk memperoleh data, maka ditempuh langkah - langkah sebagai berikut :

\section{Peralatan dan Bahan Percobaan}

Dalam penelitian biogas ini, alat dan bahan yang dipersiapkan adalah sebagai berikut :

Alat-alat :

a. Reaktor (digester) yang terdiri dari :

- Bak Pencampur

- Bak (corong) Pemasukan Bahan

- Bejana Pencerna ( memiliki pipa / kran keluaran gas)

- Bak keluaran Bahan

- Bejana pencuci dan Penampung Gas (jika perlu)

- Alat Pengaduk/pencampur

- Alat Penusuk

b. Alat Pengukur tekanan dengan metode kolom air.

c. Alat Pencatat Waktu (jam)

e. Alat Uji Kadar Air

1. Cawan Petri

2. Timbangan digital Bahan :
a. Sampah Sayur (bayam, kangkung dan kubis)
b. Stater EM4
c. Air

\section{Tahapan Pengumpulan Data}

\section{Pembuatan Gas Bio :}

- Sampah sayur dikumpulkan tiap jenis sampah sayur, kemudian sampah sayuran tersebut dibersihkan dari sampah anorganik, agar dapat mempercepat proses pembentukkan gas bio.

- Timbang masing-masing jenis sampah sayuran tersebut sebesar $30 \mathrm{~kg}$ untuk tiap jenis sampah sayuran, guna menentukan volume yang ditentukan dalam proses 
pencampuran sampah sayur dengan air.

- Kemudian masing-masing sampah sayuran tersebut dilakukan penggilingan untuk mendapatkan ukuran sampah sayuran lebih halus, agar mempermudah proses pencernaan dalam fermentasi pembentukkan gas bio.

- Dimasukkan kedalam bak dengan menggunakan corong dan ditambahkan air sehingga diperoleh bahan isian 1 : 1 air.

- Setelah bahan isian tercampur, maka tambahkan stater EM4 bakteri fermentasi sebanyak $500 \mathrm{ml}$ pada setiap jenis sampah sayur.

- Pipa pemasukan ditusuk - tusuk (jika konstruksi reaktor sempurna, maka akan masuk secara otomatis, dan di bak keluaran bahan akan terisi keluaran secara otomatis pula).

- Tutup lubang corong dengan rapat dan kedap, dengan tujuan agar tidak kemasukkan benda asing dari luar, yang dapat mempengaruhi proses dan hasil dari gas bio tersebut.

- Pengukuran tekanan gas bio yang dihasilkan dilakukan setiap pagi dan siang hari selama 7 hari setiap jenis bahan sampah sayuran.

\section{Cara Pengukuran Tekanan Gas Bio :}

- Pasang pipa pada lubang penghasil gas, kemudian ujung dari pipa tersebut letakkan pada papan.
- Bentuk ujung pipa tersebut menyerupai huruf "U" pada papan

- Isi pipa tersebut dengan air warna, sampai mendapatkan ukuran air vertikal antara sisi ujung pipa leter $U$ tersebut.

- Pasang penggaris pada sisi pipa, dengan tanda start awal $0 \mathrm{ml}$ pada ujung pipa berisi air warna.

- Pada waktu yang ditentukan, maka gas bio dapat terbaca dengan melihat kenaikkan air warna. Dan pembacaan tekanan gas dapat dihitung pada penggaris yang telah terpasang pada sisi ujung pipa.

- Pembacaan tekanan gas bio pada kolom air menggunakan satuan ml.

- Pembacaan tekanan dilakukan setiap pagi dan siang hari, pembacaan dilakukan selama 7 hari untuk setiap jenis sampah sayuran.

\section{E. Metode Analisis Data}

Setelah data yang diperoleh maka langkah selanjutnya adalah mengolah data tersebut. Data yang diperoleh ini merupakan data mentah sehingga harus diolah sesuai dengan tujuan penelitian yang telah dirumuskan untuk mendapatkan kesimpulan. Adapun metode yang digunakan dalam analisis data adalah dalam bentuk grafik dan tabel selanjutnya dilakukan pembahasan dengan jalan membandingkan antar jenis bahan sampah sayuran.

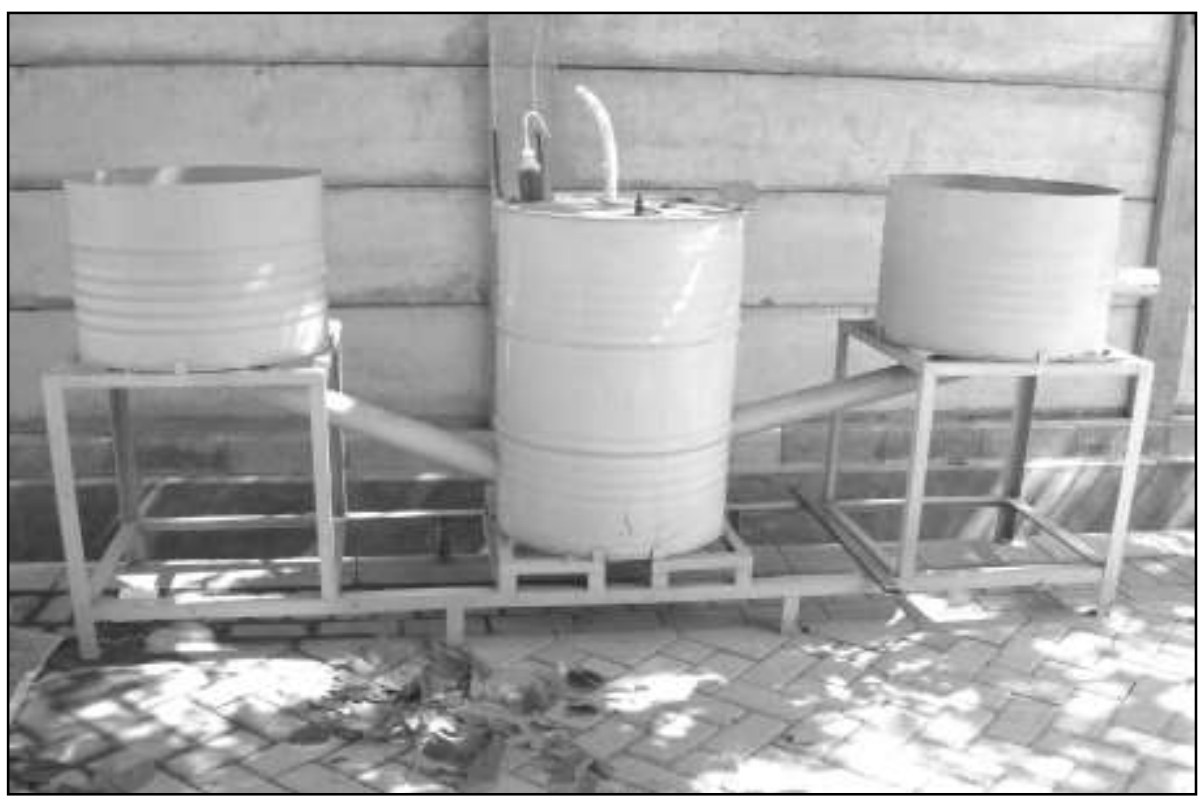

Gambar 2 : Alat Digester Biogas skala Rumah Tangga 


\section{Rancangan penelitian}

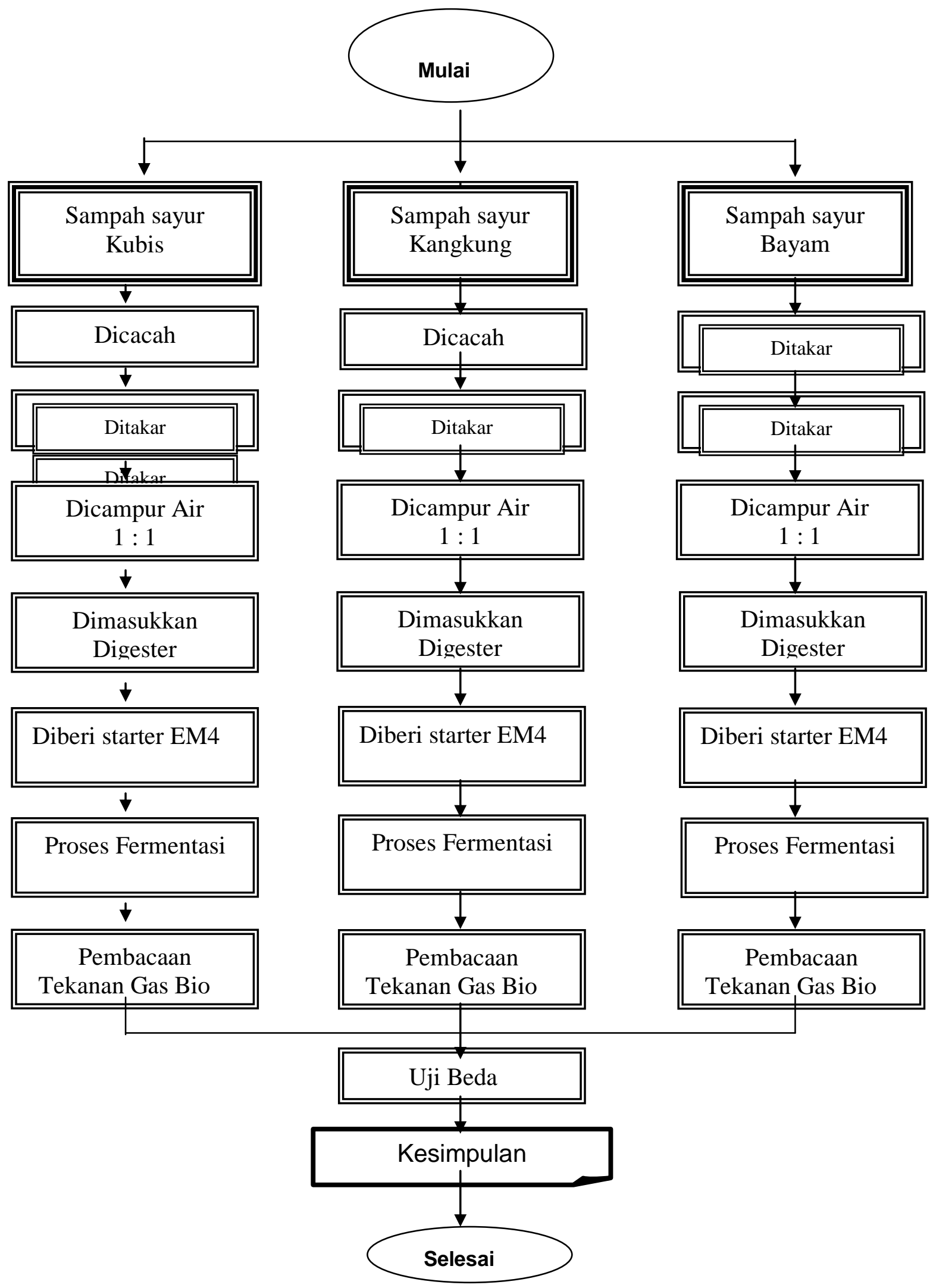

Gambar 2 : Desain Penelitian 
HASIL

Tabel 5 : Tekanan Gas di Outlet Digester

\begin{tabular}{|ccccc|}
\hline No & Variasi Bahan & $\begin{array}{c}\text { Perbandingan } \\
\text { Bahan : Air }\end{array}$ & $\begin{array}{c}\text { Tekanan } \\
\text { Maksimal } \\
\text { (mm kolom air) }\end{array}$ & $\begin{array}{c}\text { Durasi } \\
\text { pencapaian } \\
\text { Tekanan (jam) }\end{array}$ \\
\hline 1 & Kubis & $1: 1$ & 52 & 80 \\
2 & Kangkung & $1: 1$ & 55 & 152 \\
3 & Bayam & $1: 1$ & 58 & 127 \\
\hline
\end{tabular}

Sumber : Hasil Penelitian

\section{Analisis}

Untuk menganalisis pengolahan data pada tekanan gas dan lama produksi gas yang dihasilkan, maka diadakan perbandingan untuk setiap bahan uji yang berbeda - beda, guna mandapatkan hasil yang di inginkan. Metode yang digunakan dalam analisis data ini yaitu analisis secara tabel dan grafik kemudian dijelaskan dengan jalan membandingkan antar bahan yang di uji. Data yang diperoleh merupakan data dari hasil pengamatan secara langsung dilapangan. Secara keseluruhan hasil dari masing - masing bahan sampah sayuran (Kubis, Kangkung, Bayam) dilakukan pengamatan sampai dengan tekanan gas puncak dengan rentang waktu pagi dan siang hari dengan pengamatan yang terbaik dari hasil pembacaan dalam setiap harinya, namun data yang disajikan pada analisis data ini adalah data tekanan gas dimulai dari awal penelitian yaitu pada hari ke I sampai hari ke VII. Adapun data yang dianalisis yaitu antara lain :

\section{a. Data Tekanan Gas Tertinggi untuk Tiap} Bahan Sampah Sayuran

Untuk mengetahui jenis mana yang memiliki tekanan gas yang paling optimal dari ketiga bahan sayuran (Kubis, Kangkung, Bayam), maka analisa data yang ditampilkan yaitu berupa tekanan gas yang paling tinggi untuk pada setiap bahan saja. Berikut adalah tabel tekanan gas optimal untuk tiap kategori seperti yang terlihat pada tabel $\mathbf{4}$.3 dibawah ini.

Tabel 6 : Tekanan Gas Tertinggi untuk Tiap Bahan Sampah Sayur

\begin{tabular}{|l|c|}
\hline Kategori & Tekanan Gas Tertinggi (mm kolom air) \\
\hline Kubis & 52 \\
\hline Kangkung & 55 \\
\hline Bayam & 58 \\
\hline
\end{tabular}

Sumber : Hasil Pengamatan

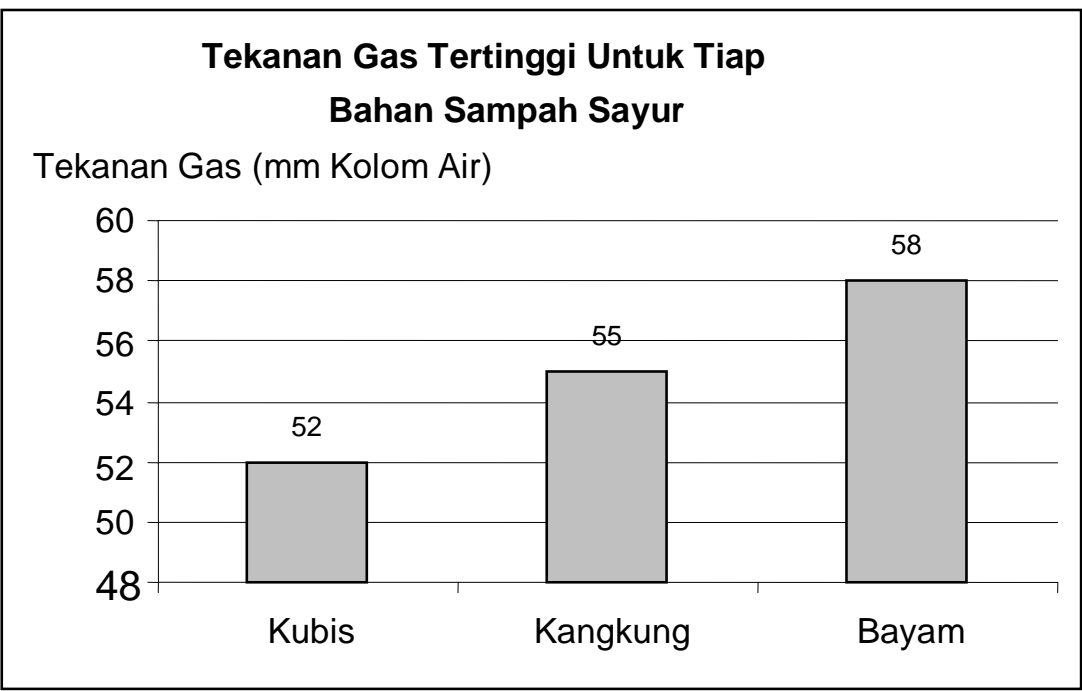

Gambar 4 : Diagram Batang Tekanan Gas Tertinggi untuk Tiap Jenis Sayuran 108 Jurnal Teknik WAKTU Volume 08 Nomor 01 Januari 2010 - ISSN : 1412 - 1867 
Dari garfik diatas terlihat, bahwa tekanan gas yang tertinggi terjadi pada bahan sampah sayur Bayam dengan tekanan gas mencapai $58 \mathrm{~mm}$ kolom air. Peningkatan produksi gas yang terjadi pada bahan sampah sayur Bayam terjadi karena dilihat dari komposisi kandungan sayuran bayam tersebut kompleks seperti mengandung kabohidrat, protein, lemak \& kadar air yang cukup tinggi yakni sebesar 86,90 mg, dari kandungan sayur Bayam tersebut dapat mempermudah bakteri dalam proses pencernaan sampah sayuran tersebut.

\section{b. Lama Produksi Gas untuk Tiap Jenis Bahan}

Dari hasil pengamatan mengenai produksi gas yang dihasilkan menunjukkan bahwa, pada bahan sampah sayur kangkung membutuhkan waktu cukup lama untuk menghasilkan tekanan gas yang maksimal dibandingkan dengan bahan sampah sayur Kubis hanya membutuhkan waktu kurang lebih 80 jam untuk menghasilkan gas yang paling optimal. Adapun data tentang tekanan gas dan lama produksi gas dapat dilihat pada tabel 7 dibawah ini.

Tabel 7 : Waktu Proses Gas untuk Tiap Jenis Bahan

\begin{tabular}{|c|c|}
\hline Kategori & Lama Produksi Biogas (Jam Ke-) \\
\hline Kubis & 80 \\
\hline Kangkung & 152 \\
\hline Bayam & 127 \\
\hline
\end{tabular}

Sumber : Hasil Penelitian

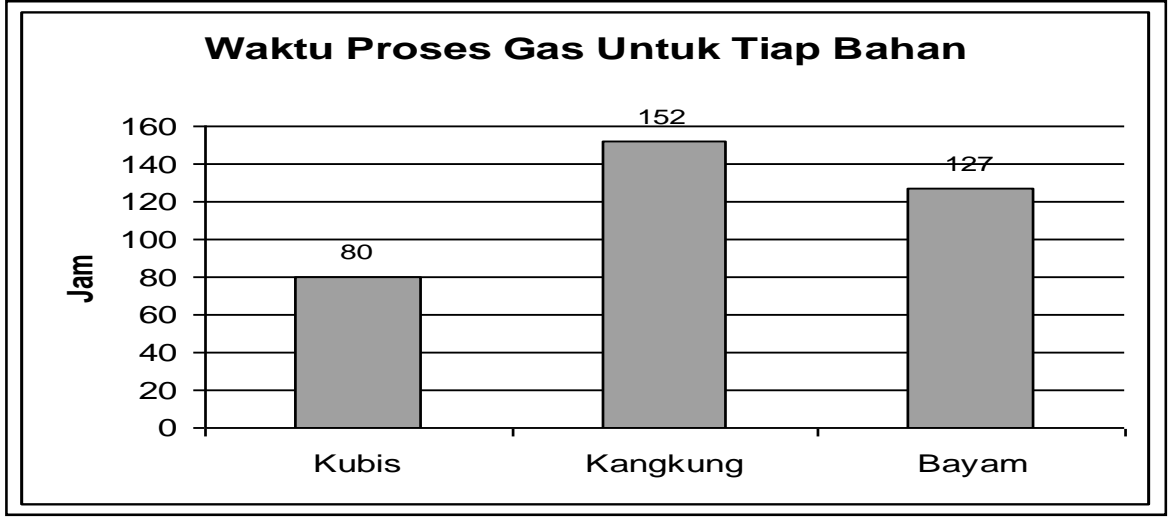

Gambar 5 : diagram Waktu Pembentukan Gas Bio tiap-tiap Variasi Bahan

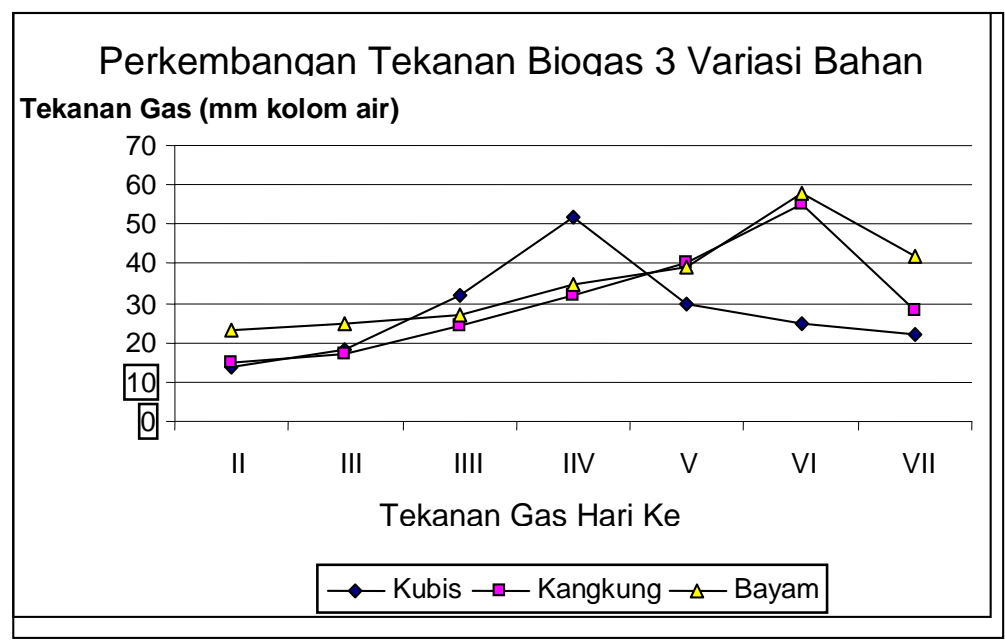

Gambar 6 : Grafik Gabungan Takanan Tiap Jenis Bahan 


\section{Pembahasan}

Dari data hasil penelitian yang tersaji di atas, dapat diinterpretasikan bahwa 3 jenis bahan sampah sayuran menghasilkan gas bio. Dalam penelitian ini bahan sampah sayuran yang memiliki hasil tekanan gas yang paling besar dari hasil pembacaan $\mathrm{mm}$ kolom air yakni bahan sampah sayuran Bayam yaitu sebesar $58 \mathrm{~mm}$ kolom air dengan waktu yang dibutuhkan 127 jam, selain itu lama produksi gas yang dihasilkan juga tidak terlalu lama bila dibandingkan dengan bahan sampah sayur Kangkung yaitu membutuhkan waktu sekitar 157 jam untuk menghasilkan gas yang lebih besar. Dari ke tiga jenis bahan sampah sayur tidak menyebabkan perbedaan signifikan pada tekanan gas yang di hasilkan dilihat dari hasil uji analisis. Sehingga tidak ada pengaruh jenis sampah sayuran dengan tekanan gas yang dihasilkan.

\section{SIMPULAN DAN SARAN}

\section{A. Simpulan}

Berdasarkan hasil penelitian yang telah dilakukan, didapatkan tekanan gas dan waktu yang dibutuhkan sampai dengan menghasilkan gas yang maksimal. Dari pernyataan diatas dapat ditarik kesimpulan bahwa :

1. Berdasarkan hasil analisis uji Anova dari ke 3 jenis sampah sayuran (Kubis, Kangkung, Bayam) menghasilkan tekanan gas bio yang tidak berbeda-beda secara signifikan.

2. Tekanan gas dan waktu yang dibutuhkan sampai dengan menghasilkan gas yang maksimal pada hasil pembacaan $\mathrm{mm}$ kolom air yang terjadi ketiga 3 bahan sampah sayuran yang telah diuji dihasilkan yakni pada bahan sampah sayuran Kubis tekanan gas bio sebesar 52 $\mathrm{mm}$ kolom air dalam waktu 80 jam, untuk Kangkung sebesar $55 \mathrm{~mm}$ kolom air dalam waktu 152 jam, dan pada sampah sayuran Bayam tekanan gas bio sebesar $58 \mathrm{~mm}$ kolom air dalam waktu 127 jam.

\section{B. Saran}

Saran yang dapat diberikan dari penelitian ini adalah sebagai berikut :

1. Bagi para peneliti akan datang diharapkan melakukan penelitian lebih lanjut mengamati effektifitas penggunaan sampah sayuran sebagai bahan pembuatan biogas yang merupakan salah satu sumber energi alternatif dalam rumah tangga, terutama dilihat dari segi ekonomi.

2. Bagi para peneliti akan datang diharapkan dapat memvariasikan jenis sampah sayuran, perbandingan stater, maupun penempatan degester dan membandingkan tingkat tekanan gas yang dihasilkan.

\section{DAFTAR PUSTAKA}

Daugherty E.C. 2001. Biomass Energy Systems Efficiency:Analyzed through a Life Cycle Assessment. Lund Univesity, New York.

Direktorat Jendral Peternakan, 1988. Potensi Energi Biogas di Indonesia., Jakarta.

ESCAP, 1977. Proceedings of the Workshop on Biogas and Other Rural Energy Resources. held at Suva, and the Roving Seminar on Rural Energy Development,' held at Bangkok, Tehran and Jakarta (Bangkok, Thailand).

ESCAP, 1980. Workshop on Biogas Technology and Utilization, Report, New Delhi.

Harahap, F., et al.,1978. Teknologi Gas Bio, Publikasi Pusat Teknologi Pembangunan, ITB, Bandung.

Instruksi Presiden, Instruksi Preiden No 1 tahun 2006 tertanggal 25 januari 2006. tentang Penyediaan dan Pemanfaatan Bahan Bakar Nabati (biofuels), sebagai Energi Alternative, Jakarta.

Suraji, Didik, 1985, Pengolahan Sampah, Surabaya : Pusat Pendidikan Tenaga Kesehatan Departemen Kesehatan

Singh, R.K and Misra, 2005. Biofels from Biomass, Department of Chemical Engineering National Institue of Technology. Rourkela, USA.

Tim Nasional Pengembangan BBN, 2007. BBN, Bahan Bakar Alternatif dari Tumbuhan Sebagai Pengganti Minyak Bumi, Jakarta

Tata Power Company, 1978 'The Kalyam Biogas Plant', Publication, Bombay, India. , 2003. Dasar - Dasar Teknologi Biogas. www.petra.ac.id. ( 27 November 2007 )

108 Jurnal Teknik WAKTU Volume 08 Nomor 01 Januari 2010 - ISSN : 1412 - 1867 
------------, 2005. Menuai Biogas dari Limbah. www.pikiran-rakyat.com ( 14 April 2008)

------------, 2005. Model Reaktor Biogas. www.reaktor.com ( 10 Oktober 2008)

, 2007. Sampah Organik Sebagai BahanBaku Biogas. www.chem-is-try. Org .com (26 Agustus 2007)

, 2003. Teknologi Digester Gas Bio Skala Rumah Tangga.

www.pikiran-rakyat.com ( 5 Desember 2007)

2004 Pengolahan Limbah Organik Menjadi Biogas www.unsoed.ac.id 
